\title{
Critical population status of the jaguar Panthera onca in the Argentine Chaco: camera-trap surveys suggest recent collapse and imminent regional extinction
}

\author{
Verónica Andrea Quiroga, Gabriel Iván Boaglio, Andrew Jay Noss \\ and Mario Santiago Di Bitetti
}

\begin{abstract}
The population of jaguars Panthera onca in the semi-arid Chaco Province is the least well-known in Argentina. Its status in the region is described only from interviews that confirmed its presence until 2003. To update information on the distribution and population density of this species we undertook three camera-trap surveys, combined with searches for sign, at sites across latitudinal and protection gradients, and 156 interviews with local inhabitants across three larger areas. The camera-trap sites were located in areas with the highest density of records in the Argentine Chaco: Copo National Park (1,204 trap days, 24 stations, $344 \mathrm{~km}$ of transects), Aborigen Reserve (1,993 trap days, 30 stations, $251 \mathrm{~km}$ of transects) and El Cantor (2,129 trap days, 35 stations, $297 \mathrm{~km}$ of transects). We did not obtain any photographs of jaguars. We recorded very few jaguar tracks, and only in the Aborigen Reserve $(\mathrm{n}=3)$ and El Cantor $(n=1)$. The map of distribution points confirmed through interviews suggests that the jaguar range has not changed significantly in the past 10 years; however, the camera-trap and sign surveys suggest that densities are extremely low. Before our study the Chaco population was thought to be the largest in Argentina. This perception was incorrect: the Chaco jaguar population is the most threatened in the country. Systematic, intensive studies are essential to provide the necessary information for decisionmaking for the management and conservation of threatened species.
\end{abstract}

\footnotetext{
VERÓNICA ANDREA QUiRogA* (Corresponding author) and MARIO SANTIAGo DI BitETTI National Research Council of Argentina, Instituto de Biología Subtropical-nodo Iguazú, Facultad de Ciencias Forestales, Universidad Nacional de Misiones, Argentina, and Asociación Civil Centro de Investigaciones del Bosque Atlántico, Puerto Iguazú, Misiones, Argentina E-mail veroquiroga@gmail.com

Gabriel Iván BoAglio Proyecto Elé, Dirección de Fauna Silvestre, Secretaría de Ambiente y Desarrollo Sustentable, Argentina, and Asociación para la Conservación y el Estudio de la Naturaleza, Córdoba Capital, Argentina

ANDREW JAY Noss University of Florida, Gainesville, Florida, USA

*Also at: Asociación para la Conservación y el Estudio de la Naturaleza, Córdoba Capital, Argentina

Received 7 February 2012. Revision requested 14 March 2012.

Accepted 11 June 2012. First published online 30 July 2013
}

Keywords Argentina, Chaco, conservation, distribution, interview, monitoring, Panthera onca, presence

\section{Introduction}

The distribution of the jaguar Panthera onca in 1 Argentina has declined by $>90 \%$ and $<200$ individuals survive in three isolated regions: the Atlantic Forest, the Yungas and the Chaco forest (Di Bitetti et al., in press). The jaguar is a National Natural Monument protected by national and provincial laws, although these are rarely enforced. The most recent national categorization based on IUCN criteria considers the species Critically Endangered in Argentina (Di Bitetti et al., in press). The Argentine jaguar population is at the southern limit of the species' range. Therefore, it may be more vulnerable to human activities and persist at lower densities than populations nearer to the centre of the species' range, enduring ecosystems with marginal climatic conditions and low productivity, as do jaguars at the northern limit of their range in the south-west USA (Gaston et al., 1997; Laliberte \& Ripple, 2004; Yackulic et al., 2011). However, in Argentina the Chaco is not the historical limit of the species' range (it was formerly present in northern Patagonia, 1,500 km further south), rather it became so only after a considerable contraction of the regional range caused by intensive land conversion combined with heavy hunting pressure (Di Bitetti et al., in press).

The extreme isolation, aridity and high temperatures of the Argentine Chaco have resulted in the Chaco jaguar population being the least known and studied of the country's three populations. There have been only two previous studies of jaguars in the region. One short cameratrap survey attempted to estimate population density in Copo National Park (Denapole, 2007) but did not record jaguars. The second, broader study, based on interviews with inhabitants and the compilation of information on jaguar records, evaluated jaguar distribution across the whole Argentine Chaco (Altrichter et al., 2006). Better knowledge of the situation of jaguars in the Argentine Chaco is necessary because this region has been identified as 


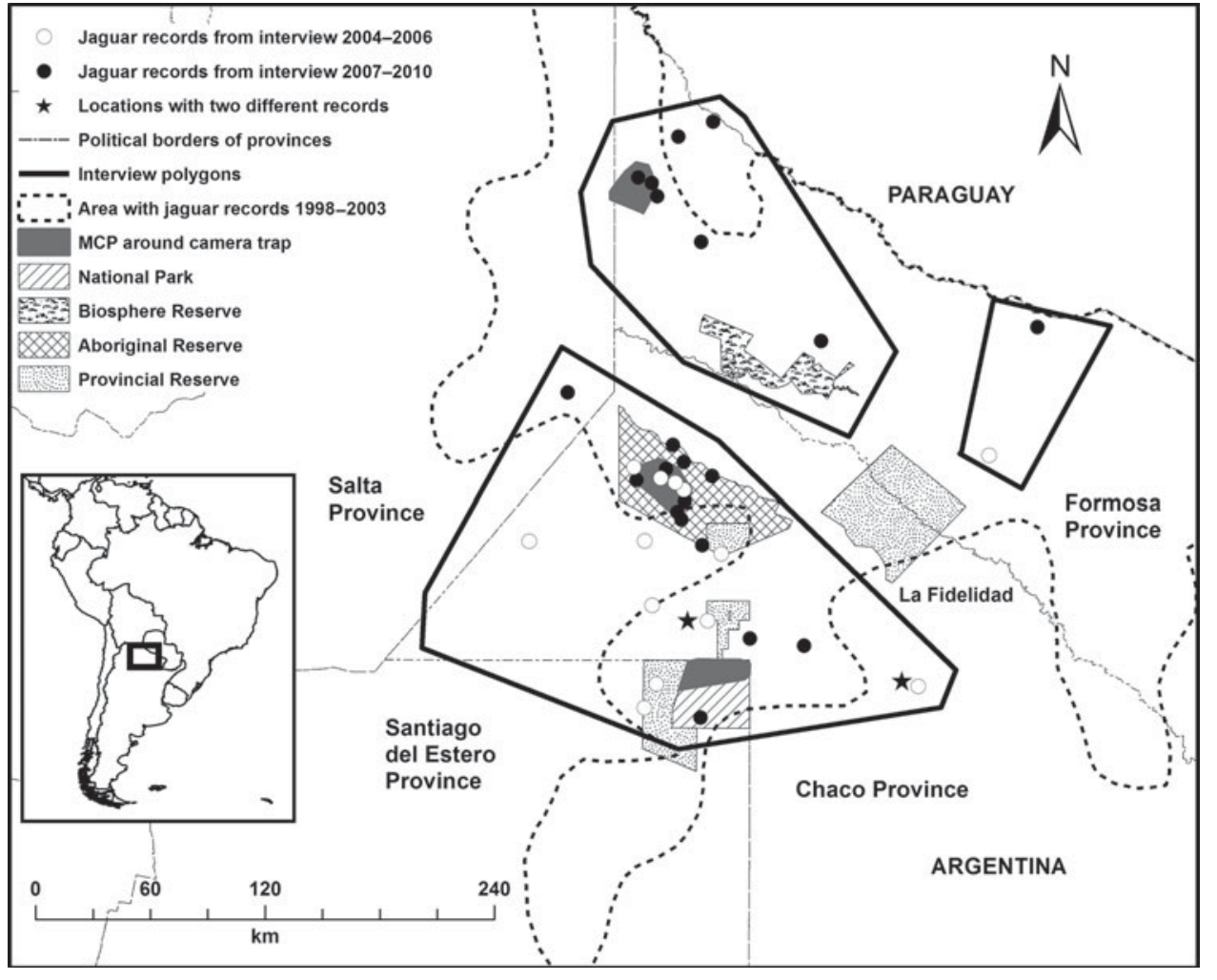

FIg. 1 The study area in the Argentine semi-arid Chaco, with the three extensive areas surveyed using interviews during 2004-2010, minimum convex polygons of the three camera trap surveys (20082010), and the locations of 35 jaguar records obtained during the interviews. The rectangle on the inset indicates the location of the main map in Argentina. a Jaguar Conservation Unit (Sanderson et al., 2002) and is important for connectivity with other areas where jaguars persist, such as the Bolivian and Paraguayan Chaco as well as the Argentine and Bolivian Yungas forests (Rabinowitz \& Zeller, 2010; Rumiz et al., 2011).

For species that are difficult to detect because of their low population density or behaviour, studies in other regions have used presence records to evaluate the status of the population (Perovic et al., 2003; De Angelo et al., 2011; Karanth et al., 2011a; Pereira Munari et al., 2011; Salvador et al., 2011). Such information allows investigators to develop a baseline for a species' distribution and to identify favourable research sites, particularly when information is scarce or non-existent. However, presence data and distribution maps alone are not sufficient to determine the conservation status of threatened species (Can \& Togan, 2009; Karanth et al., 2011b). Altrichter et al. (2006) provided information on the range of the jaguars in the region up to 2003 but they focused on interviewing local residents, and did not have information about whether reports represented a few wandering male jaguars or a reproducing population. We evaluated the density of the jaguar in areas of various categories of legal protection and intensities of hunting and ranching in the Argentine Chaco using the first large-scale camera-trap survey in the region. We also evaluated whether presence data reflect the conservation status and current range of the species in the region, and whether stable populations persist at each site.

\section{Study area}

The Gran Chaco is the second-most extensive forest in the Americas and it is the largest subtropical dry forest (Morello \& Adámoli, 1974; Morello et al., 2009). Sixty percent of the Chaco $\left(675,000 \mathrm{~km}^{2}\right)$ is in Argentina and c. $270,000 \mathrm{~km}^{2}$ are semi-arid Chaco forests. The Argentine semi-arid Chaco comprises dry forest plains with a marked seasonal climate, a median annual temperature of $24^{\circ} \mathrm{C}$ and annual precipitation of $400-800 \mathrm{~mm}$, falling mostly in OctoberApril. The area was colonized early in the 2oth century by non-indigenous people who settled on isolated ranches. The region also has many indigenous settlements. The characteristics of the region support an extensive cattle ranching system, combined with heavy hunting of wildlife both by local inhabitants and by hunters from nearby towns (Baxendale \& Buzai, 2009).

We compared three sites across a north-south gradient (Fig. 1) and across a gradient of conditions related to hunting pressure, livestock burden and legal protection status (Table 1).

Copo National Park is the site with the highest degree of protection within the study area. Although there are a few small human settlements near the Park, only one person lives inside the surveyed portion of the Park and the livestock burden is the lowest of any of the surveyed sites. Lacking roads and trails, the interior of Copo National Park is inaccessible and therefore hunting pressure is very low. 


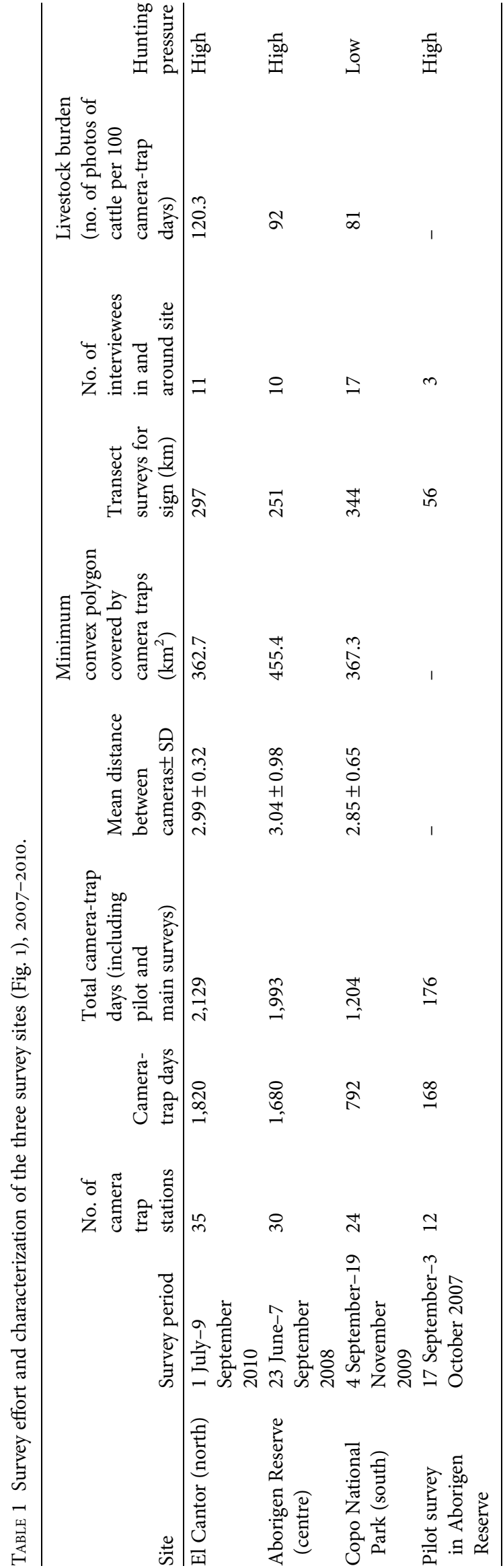

Aborigen Reserve is not a protected area but because it is categorized as an indigenous reserve it is sparsely populated and has an intermediate livestock burden relative to the other two survey sites. Three roads cross the reserve and facilitate access by hunters.

El Cantor is not legally protected but is considered a candidate for the creation of a protected area (Brown et al., 2010). The site is currently inhabited and people hunt wildlife there. The livestock burden is the highest of the three study sites.

\section{Methods}

We worked at two different scales to generate two types of information: fine-scale data were generated by camera traps, line transects and track plots to estimate presence, number of individuals and density, based on captures and recaptures; and coarse-scale presence-absence data were generated through interviews, to determine the species' regional distribution. In the camera-trap surveys we established 25-35 camera stations, each with two camera traps facing each other across foot trails or low-transit dirt roads (Table 1). The camera pairs provided simultaneous photographs of both sides of individual animals, facilitating the identification of individuals and determination of abundance (Karanth \& Nichols, 2002; Maffei et al., 2002; Paviolo et al., 2008). To generate presence and relative abundance data we walked transects daily to record jaguar, puma and prey data through direct observations and through signs such as tracks, claw marks on trees and scats (Carrillo et al., 2000; Silveira et al., 2003). To ensure correct identification of jaguar and puma tracks we photographed them with a size reference and applied automated software for identifying tracks using keys and discriminant models (De Angelo et al., 2010). The number of $\mathrm{km}$ surveyed at each site (Table 1 ) was determined by the number of footpaths and abandoned roads available, and logistics.

We conducted shorter preliminary surveys at the three sites to familiarize ourselves with the area and adjust our methodologies (Table 2). In the Aborigen Reserve we conducted two preliminary surveys, using $75-90$ track plots, to generate presence data. We cleared $1 \times 1 \mathrm{~m}$ square track plots $50 \mathrm{~m}$ apart, sifting soil to create a better surface for detecting tracks, along footpaths that were $2 \mathrm{~km}$ long and at least $6 \mathrm{~km}$ apart. We checked track plots once per day, identifying and counting any tracks and then clearing the plots again, for 4-6 days.

During the coarse-scale survey in 2004-2010 we conducted informal interviews (Marker et al., 2003; Figel et al., 2011) over a vast area, to generate jaguar presenceabsence data and to compare our results with the only previous information for the species in the region 
TABLE 2 Methods and survey periods across the three principal sites.

\begin{tabular}{|c|c|c|c|c|}
\hline \multirow[b]{2}{*}{ Site } & \multicolumn{2}{|l|}{ Preliminary survey } & \multicolumn{2}{|l|}{ Complete survey } \\
\hline & Methods & Dates & Methods & Dates \\
\hline El Cantor & $\begin{array}{l}\text { Walking trails for sign, } \\
\text { interviews }\end{array}$ & June 2010 & $\begin{array}{l}\text { Camera traps, walking trails } \\
\text { for sign, interviews }\end{array}$ & June-September 2010 \\
\hline Aborigen Reserve & $\begin{array}{l}\text { Track-plots, walking } \\
\text { trails for sign, interviews } \\
\text { Camera traps }\end{array}$ & $\begin{array}{l}\text { June \& October } \\
2006 \\
\text { September-October } \\
2007\end{array}$ & $\begin{array}{l}\text { Camera traps, walking trails } \\
\text { for sign, interviews }\end{array}$ & June-September 2008 \\
\hline Copo National Park & $\begin{array}{l}\text { Walking trails for sign, } \\
\text { interviews }\end{array}$ & July 2009 & $\begin{array}{l}\text { Camera traps, walking trails } \\
\text { for sign, interviews }\end{array}$ & September-November 2009 \\
\hline
\end{tabular}

TABLE 3 Jaguar records for the three principal survey sites, by methodology.

\begin{tabular}{llll}
\hline Site & $\begin{array}{l}\text { Camera trap } \\
\text { records }\end{array}$ & Tracks from transect surveys \& track plots & Interview records (2004-2010) \\
\hline El Cantor & 0 & 1 & Yes \\
Aborigen Reserve & 0 & $1(+2$ records during pilot survey in 2006) & Yes \\
Copo National Park & 0 & 0 & Yes (but no records post 2008) \\
\hline
\end{tabular}

(Altrichter et al., 2006). We interviewed 156 people, including local residents, rural teachers, park guards and other researchers in the region. These interviews were conducted opportunistically over a total of 20 field trips, both during jaguar-specific field research and during research on other species. Twelve field trips of 15-45 days each were focused specifically on interviews. Interviews were undertaken in three regions (Fig. 1) that included the camera-trap sites and the region identified by Altrichter et al. (2006) as having the highest probability of jaguar presence (Fig. 1). In the interviews we asked about (1) current and historical jaguar presence in the area, (2) the number of years since the last encounter (direct sighting or tracks) with the species, (3) conflicts between jaguars and livestock, (4) the number of jaguars killed recently or historically in the area and the motives for the killings, and (5) skins or other remains of jaguars killed. Finally, we asked about the interviewee's general knowledge of the jaguar, to determine whether they knew the species.

The interviews, rather than using structured questions, were part of a general, informal conversation in which we solicited information about jaguars as far as cordial exchange with the interviewee permitted. The types of questions and the way we posed them varied according to the interviewee and the situation. We were previously acquainted with most of the local inhabitants and they trusted us sufficiently to provide sensitive information, particularly about jaguars hunted or conflicts with the species. With respect to jaguar tracks reported by local people, without having photographs or plaster casts we could not confirm identifications using the discriminant analysis that we applied to the track data that we collected.
Nevertheless we collected these data because local knowledge is particularly important in complementing other data when monitoring rare and elusive species, recognizing that there are higher degrees of error when comparing with other types of data. To avoid biases we considered data to be valid only if provided by people whom we knew were knowledgeable about the species and could clearly describe the typical characteristics that facilitate discrimination between jaguar and puma tracks, or provide clear descriptions of how the prey was killed and consumed. If a record was doubtful but we could confirm the information, we did so before including the record in our sample. Data from unreliable informants and which we could not corroborate were discarded. Thus our records from informants were collected in a similar manner to those reported by Altrichter et al. (2006), with which we compare our results.

\section{Results}

We did not obtain camera-trap records of jaguars at any of the sites. Only in the Aborigen Reserve and in El Cantor did we ourselves observe jaguar tracks. Three of the track records were in the Aborigen Reserve, one in each track plot survey (June and October 2006) and the other during the 2008 camera-trap survey at this site. The other track record was at El Cantor during 2010 (Table 3). Both records from 2006 were identified as jaguar tracks with a probability $>93 \%$. The 2008 and 2010 track records were identified as jaguar tracks with a probability $>99 \%$. In each case the tracks were from a single individual recorded only once during the field survey. 
Of 156 people interviewed, only $20 \%$ reported jaguar data for 2004-2010, and $80 \%$ said they had not seen jaguars or signs for many years or that jaguars no longer existed in the region. A total of 31 independent records were obtained through interviews. Together with our four track records, we obtained 35 independent records of jaguar presence (Fig. 1). The majority of the records since 2007 were limited to the northern and eastern parts of the study area (Fig. 1), despite a similar survey effort during the same period in the south. Of the 35 records, 13 were direct observations of the species, with confirmation of at least one female with a cub (central Formosa Province, 2005), a juvenile (Aborigen Reserve, 2008) and a further two solitary females (one in Loro Hablador Provincial Park in 2004 and the other near the Aborigen Reserve, both in Chaco Province). Of the three records of livestock predation, one was in 2004 near the Loro Hablador Provincial Park and the other two were in Formosa during 2010, one at a ranch in the Bañados de la Estrella and the other at a ranch near Posta Zalazar, $4 \mathrm{~km}$ and $<10 \mathrm{~km}$ from the Paraguayan border, respectively. Two records are of jaguars killed in 2007: one in Palmar Largo, Formosa (40 km north of El Cantor) and the other north of the Aborigen Reserve at El Recreo ranch, Chaco Province, along the Bermejito River. The remaining 17 records were tracks: four we confirmed ourselves and 13 were reported by interviewees.

\section{Discussion}

Of the $79,000 \mathrm{~km}^{2}$ that Altrichter et al. (2006) described as the distribution of the jaguar in the Argentine Chaco up to 2003, we surveyed c. 60\% during 2004-2010. Our range map and the overall pattern of jaguar presence records are broadly similar to the findings of Altrichter et al. (2006). We could therefore conclude that the jaguar population has not suffered any important change between the two studies. However, distribution maps based on such records may indicate the existence of transients or survivors rather than a stable population if only wandering males occur in the area, for example (Boydston \& López González, 2005; Hoogesteijn \& Hoogesteijn, 2005; Conde et al., 2010). Presence data alone do not facilitate a precise evaluation of population status, particularly when generated only from interviews. For this reason we emphasize the importance of specific and systematic studies to confirm the status of particular populations, especially when data are required to make management decisions for the conservation of threatened species (Karanth et al., 2011b). Currently, general and wide-ranging studies (Altrichter et al., 2006; De Angelo et al., 2011) or rapid biological inventories (Torres \& Jayat, 2010) are commonly employed to provide baseline information on the conservation status of particular species or for decision-making on management measures for conservation. Although such studies are useful for generating information quickly or over large areas, they should never replace intensive focused studies. Because it is superficial and imprecise, coarse-scale information does not clearly reflect the status of a species (Silveira et al., 2003; Karanth et al., 2011b).

Prior to our study it was presumed that the Chaco population was one of the largest in Argentina because of the vast area of the region, the high percentage of native forest cover, the low human population density and the previous range maps based on presence information (Altrichter et al., 2006; Di Bitetti et al., in press). This perception was incorrect: the population is the most threatened in the country. Our survey was one of the most extensive jaguar studies conducted to date (Maffei et al., 2004, 2011a,b; Paviolo et al., 2008; De la Torre \& Medellín, 2011). However, the camera-trap capture rate for jaguars in similar studies in the Bolivian Chaco (Maffei et al., 2004), and even in regions with much lower jaguar density, such as Argentina's Atlantic Forest (Paviolo et al., 2008), was 2-20 and 1.34-14 photographs per 1,00o trap nights, respectively, in contrast with no records in 5,326 camera-trap nights in our study. Jaguars may live at lower densities in the Argentine Chaco compared to more humid areas, assuming lower resource availability in this arid region. However, given that the Bolivian Chaco has similar rainfall and environmental conditions to the sites surveyed in the Argentine Chaco, the lack of camera-trap photographs indicates an extremely low jaguar density and perhaps extinction at some sites. Probable causes are the arid environment, lower prey availability, historically high hunting pressure and the intrinsic vulnerability of living at the boundary of the species' current range (Gaston et al., 1997; Yackulic et al., 2011).

A relatively reliable indicator of the presence of the jaguar is the frequency of hunted animals reported in interviews, particularly in areas where jaguars are systematically eliminated by local people, as is the case in the Chaco. Comparing the frequency of each type of presence record in our study with the frequencies reported by Altrichter et al. (2006) for the period 1993-2003, the hunting records are those that diminish the most between the two periods $\left(\chi^{2}=6.05, \mathrm{df}=1, \mathrm{P}<0.02\right)$. Hunted animals represent only $2 \%$ of our records from interviews, compared with $23 \%$ of records a decade ago. In the Argentine Chaco the jaguar population has declined as a result of hunting, such that well-conserved forest sites no longer maintain jaguars (Altrichter et al., 2006). Hunting of jaguars and other large mammals has been part of the lifestyle of Chaco residents since the region was colonized (Altrichter, 2006) and the absence of jaguars is directly related to the age of ranch settlements (Altrichter et al., 2006). This implies that jaguar density should be higher within protected areas relative to less well-protected areas (Paviolo et al., 2008). 
During 2002-2010 there were notable environmental changes in the Chaco (Torrella \& Adámoli, 2006; Gasparri \& Grau, 2009). Jaguar distribution may also be affected by large-scale habitat loss and the fragmentation of remaining forest patches into small parks and reserves with little or no connectivity (Matteucci, 2009; De Angelo et al., 2011).

Studies of threatened large felids suggest a general pattern of higher probability of presence and higher abundance in relatively large areas that are well conserved, effectively managed and interconnected (Maffei et al., 2004; Novack et al., 2005; Datta et al., 2008; Paviolo et al., 2008; Rabinowitz \& Zeller, 2010; Yackulic et al., 2011). However, the results of the survey conducted in Copo National Park in 2009 suggest that the jaguar population is extremely small or that the species may recently have gone extinct in this protected area. Given that Copo National Park is the southernmost limit of the species' distribution in the Chaco, of the three survey sites it could be the area most vulnerable to extinction (Brown, 1984; Gaston et al., 1997; Laliberte \& Ripple, 2004). Copo is surrounded by ever more intensive productive activities and is becoming isolated by forest clearing for farming and ranching from the neighbouring Loro Hablador Provincial Park, which had served as a corridor connecting Copo with forested areas to the north (Matteucci, 2009). A corridor among protected areas in the region would reduce the isolation of Copo and potentially facilitate recolonization of the Chaco. For this reason the conservation and management of Copo are regional priorities.

The advance of the agricultural frontier in the Argentine Chaco means not only habitat loss and fragmentation but also a more extensive network of roads, and thus facilitates access by hunters (Morello et al., 2006). This has probably put greater pressure on the jaguar, as has occurred elsewhere (Maffei et al., 2004). The status of the jaguar in the Paraguayan and Bolivian Chaco is notably different. Jaguar photographs have been obtained with much lower cameratrap effort and direct and indirect observations are common (Maffei et al., 2004; McBride, 2009). The marked difference between countries in this respect could be a result of their historical differences in land use. The Argentine Chaco has a longer history of colonization by descendants of Europeans, who maintained a strong hunting tradition (Altrichter, 2006; Morello et al., 2006). In contrast, the Paraguayan and Bolivian Chaco still contain vast areas that are uninhabited and relatively inaccessible (Taber et al., 1997; Maffei et al., 2004; Rumiz et al., 2011). The long-term presence of cattle in the Argentine Chaco has probably also affected jaguars, because ranchers hunt jaguars in response to real or perceived conflicts with livestock (Hoogesteijn \& Hoogesteijn, 2005; Arispe et al., 2009).

Nevertheless, of the total area of Chaco forest that is potential jaguar habitat, our camera-trap surveys covered $<1.5 \%$. Other sites in the region must be surveyed as a matter of urgency, to determine whether the jaguar is now rare across the whole semi-arid Chaco. The creation of corridors linking existing protected areas and the effective management of corridors and protected areas so that they provide refuge and protection for the species are high priorities. Recent conservation efforts include the proposal for a new National Park in La Fidelidad $\left(2,500 \mathrm{~km}^{2}\right)$. At only $20 \mathrm{~km}$ east of the Aboriginal Reserve (Fig. 1), there are jaguars present in the forest of La Felidad, but the status of this population has not yet been evaluated (Rumiz et al., 2011). The establishment of this Park would provide jaguars with large and well-conserved core areas, which could maintain populations. The protection of the few remaining well-conserved forests that connect the Argentine Chaco with the Yungas in Argentina is also important. Such corridors, to the Yungas as well as to the Paraguayan Chaco, ensure connectivity of jaguars in the Argentine Chaco with the southernmost populations of the species (Sanderson et al., 2002; Rabinowitz \& Zeller, 2010; Rumiz et al., 2011).

We recommend that the government of Argentina takes measures to conserve jaguar habitat in the Chaco and protect the species and its prey from illegal hunting. The environmental conditions of the Argentine Chaco remain suitable for maintenance of a viable jaguar population if illegal hunting can be controlled and deforestation halted.

\section{Acknowledgements}

We thank the volunteers who helped with field work; the Agency of Wildlife, Parks and Ecology, Chaco Province; the Ministry of Production and Environment, Formosa Province; Copo National Park, the National Parks Administration; the National University of Córdoba; the National Wildlife Service, National Environment and Sustainable Development Secretariat. Financial and logistical support was provided by CONICET-Argentina, Jaguar Conservation Program-WCS, Rufford Small Grants Foundation, Cleveland Metroparks Zoo and Cleveland Zoological Society, Mohamed bin Zayed Species Conservation Fund, Idea Wild, Elé Project, Stephen F. Austin State University, Yaguareté Project Misiones and Tapir Project Salta. We thank Pablo Perovic, Ricardo Banchs, Gustavo Porini, Adrián Díaz, Daniel Scognamillo, Andrés Ravelo, Agustín Paviolo, Peter Feinsinger and Susan Walker for their support and advice at different stages of this project.

\section{References}

Altrichter, M. (2006) Wildlife in the life of local people of the semiarid Argentine Chaco. Biodiversity and Conservation, 15, 2719-2736.

Altrichter, M., Boaglio, G. \& Perovic, P. (2006) The decline of jaguars Panthera onca in the Argentine Chaco. Oryx, 40, 302-309. 
Arispe, R., Rumiz, D., Venegas, C. \& Noss, A. (2009) El conflicto de la depredación de ganado por el jaguar (Panthera onca) en Santa Cruz, Bolivia. Manejo de Fauna en Latinoamérica (revista electrónica), 1-23.

Baxendale, C.A. \& Buzai, G.D. (2009) Caracterización socioespacial del chaco argentino. In El Chaco sin bosques: la Pampa o el desierto del futuro (eds J.H. Morello \& A.F. Rodríguez), pp. 3-52. Orientación Gráfica Editora, Buenos Aires, Argentina.

Boydston, E.E. \& López González, C.A. (2005) Sexual differentiation in the distribution potential of northern jaguars (Panthera onca). USDA Forest Service Proceedings, RMRS-P-36, 51-56.

Brown, J.H. (1984) On the relationship between abundance and distribution of species. American Naturalist, 124, 255-279.

Brown, A.D., Foguet, M.J., García Moritan, M. \& Malizia, S. (2010) Bitácora Bañados de la Estrella: dinámica fluvial de un espacio compartido. Ediciones del Subtrópico, Tucumán, Argentina.

CAN, Ö.E. \& Togan, I. (2009) Camera trapping of large mammals in Yenice Forest, Turkey: local information versus camera traps. Oryx, 43, 427-430.

Carrillo, E., Wong, G. \& Cuarón, A.D. (2000) Monitoring mammal populations in Costa Rican protected areas under different hunting restrictions. Conservation Biology, 14, 1580-1591.

Conde, D.A., Colchero, F., Zarza, H., Christensen, N.L. Jr., Sexton, J.O., Manterota, C. et al. (2010) Sex matters: Modeling male and female habitat differences for jaguar conservation. Biological Conservation, 143, 1980-1988.

Datta, A., Anand, M.O. \& Naniwadekar, R. (2008) Empty forests: Large carnivore and prey abundance in Namdapha National Park, north-east India. Biological Conservation, 141, 1429-1435.

De Angelo, C., Paviolo, A. \& Di Bitetti, M. (2010) Traditional versus multivariate methods for identifying jaguar, puma, and large canid tracks. Journal of Wildlife Management, 74, 1141-1153.

De Angelo, C., Paviolo, A. \& Di Bitetti, M. (2011) Differential impact of landscape transformation on pumas (Puma concolor) and jaguars (Panthera onca) in the Upper Paraná Atlantic Forest. Diversity and Distributions, 17, 422-436.

De la Torre, J.A. \& Medellín, R. (2011) Jaguars Panthera onca in the Greater Lacandona Ecosystem, Chiapas, Mexico: population estimates and future prospects. Oryx, 45, 546-553.

Denapole, L. (2007) Jaguar (Panthera onca), puma (Puma concolor) $y$ presas en el Parque Nacional Copo, Santiago del Estero-Argentina. MSc thesis, Programa Regional en Manejo de Vida Silvestre para Mesoamérica y el Caribe, Costa Rica.

Di Bitetti, M., Quiroga, V., De Angelo, C., Altrichter, M., Paviolo, A., Cuyckens, E. et al. (In press) El yaguareté (Panthera onca) en la Argentina: situación poblacional, amenazas y acciones para su conservación. In Manejo de Fauna en la Argentina. Acciones para la Conservación de Especies Amenazadas. Dirección de Fauna de la Nación Argentina (eds D. Ramadori \& G. Porini). Secretaría de Ambiente de la Nación Editora, Beunos Aires, Argentina.

Figel, J.J., DurÁn, E. \& BRAY, D.B. (2011) Conservation of the jaguar Panthera onca in a community-dominated landscape in montane forests in Oaxaca, Mexico. Oryx, 45, 554-560.

Gasparri, N.I. \& Grau, H.R. (2009) Deforestation and fragmentation of Chaco dry forest in NW Argentina (1972-2007). Forest Ecology and Management, 258, 913-921.

Gaston, K.J., Blackburn, T.M. \& Lawton, J.H. (1997) Interspecific abundance-range size relationships: an appraisal of mechanisms. Journal of Animal Ecology, 66, 579-601.

Hoogesteijn, R. \& Hoogesteijn, A. (2005). Manual sobre problemas de depredación causados por grandes felinos en hatos ganaderos.
Programa de Extensión para Ganaderos. Programa de Conservación del Jaguar. Wildlife Conservation Society, Campo Grande, Brazil.

Karanth, K.U. \& Nichols, J.D. (2002) Monitoring Tigers and Their Prey: A Manual for Researchers, Managers, and Conservationists in Tropical Asia. Centre of Wildlife Studies, Bangalore, India.

Karanth, K.U., Gopalaswamy, A.M., Kumar, N.S., Vaidyanathan, S., Nichols, J.D. \& MacKenzie, D.I. (2011a) Monitoring carnivore populations at the landscape scale: occupancy modelling of tigers from sign surveys. Journal of Applied Ecology, 48, 1048-1056.

Karanth, K.U., Gopalaswamy, A.M., Kumar, N.S., Delampady, M., Nichols, J.D., Seidensticker, J. et al. (2011b) Counting India's wild tigers reliably. Science, 332, 791.

Laliberte, A.S. \& Ripple, W.J. (2004) Range contractions of North American carnivores and ungulates. BioScience, 54, 123-128.

Maffei, L., Cuellar, E. \& Noss, A. (2002) Uso de trampas-cámara para la evaluación de mamíferos en el ecotono Chaco-Chiquitanía. Revista Boliviana de Ecología, 11, 55-65.

Maffei, L., Cuellar, E. \& Noss, A. (2004) One thousand jaguars (Panthera onca) in Bolivia's Chaco? Camera trapping in the Kaa-Iya National Park. Journal of Zoology, 262, 295-304.

Maffei, L., Polisar, J., Garcia, R., Moreira, J. \& Noss, A.J. (2011a) Perspectives from ten years of jaguar (Panthera onca) camera trapping in Mesoamerica. Mesoamericana, 15, 49-59.

Maffei, L., Noss, A.J., Silver, S. \& Kelly, M.J. (2011b). Abundance/ density case study: jaguars in the Americas. In Camera Traps in Animal Ecology: Methods and Analyses (eds A.F. O'Connell Jr., J.D. Nichols \& U.K. Karanth), pp. 119-144. Springer Inc., Tokyo, Japan.

Marker, L.L., Mills, M.G.L. \& Macdonald, D.W. (2003) Factors influencing perceptions of conflict and tolerance toward cheetahs on Namibian farmlands. Conservation Biology, 17, 1290-1298.

Matteucci, S.D. (2009) Cambios del uso de la Tierra en el entorno de las áreas protegidas en la llanura chaqueña. Posibles consecuencias sobre la efectiviad de las reservas naturales. In El Chaco sin bosques: la Pampa o el desierto del futuro (eds J.H. Morello \& A.F. Rodríguez), pp. 373-402. Orientación Gráfica Editora, Buenos Aires, Argentina.

McBride, R. (2009) Project Jaguar - Final Report. Faro Moro Eco Research, Moises Bertoni Foundation, Paraguay Ministry Of Environment, Asunción del Paraguay, Paraguay.

Morello, J. \& AdÁmoli, J. (1974) Las grandes unidades de vegetación $y$ ambiente del Chaco argentino. Segunda Parte: Vegetación y ambiente de la Provincia del Chaco. Serie Fitogeográfica 13. Instituto de Botánica Agricola, Buenos Aires, Argentina.

Morello, J., Pengue, W. \& Rodríguez, A. (2006) Etapas de uso de los recursos y desmantelamiento de la biota del Chaco. In $L a$ Situación Ambiental Argentina 2005 (eds A. Brown, U. Martinez Ortiz, M. Acerbi \& J. Corchera), pp. 83-90. Fundación Vida Silvestre Argentina, Buenos Aires, Argentina.

Morello, J.H., Rodríguez, A.F. \& Silva, M. (2009) Clasificación de ambientes en áreas protegidas de las ecorregiones del chaco húmedo y chaco seco. In El Chaco sin bosques: la Pampa o el desierto del futuro (eds J.H. Morello \& A.F. Rodríguez), pp. 53-92. Orientación Gráfica Editora, Buenos Aires, Argentina.

Novack, A.J., Main, M.B., Sunquist, M.E. \& Labisky, R.F. (2005) Foraging ecology of jaguar (Panthera onca) and puma (Puma concolor) in hunted and non-hunted sites within the Maya biosphere Reserve, Guatemala. Journal of Zoology, 267, 167-178.

Paviolo, A., De Angelo, C., Di Blanco, Y. \& Di Bitteti, M. (2008) Jaguar population decline in the Upper Paraná Atlantic Forest of Argentina and Brazil. Oryx, 42, 554-561.

Pereira Munari, D., Keller, C. \& Venticinque, E.M. (2011) An evaluation of field techniques for monitoring terrestrial mammal populations in Amazonia. Mammalian Biology, 76, 401-408. 
Perovic, P., Walter, S. \& Novaro, A. (2003) New records of the Endangered Andean mountain cat in northern Argentina. Oryx, 37, 374-377.

Rabinowitz, A. \& Zeller, K.A. (2010) A range-wide model of landscape connectivity and conservation for the jaguar, Panthera onca. Biological Conservation, 143, 949-945.

Rumiz, D.I., Polisar, J. \& Maffei, L. (eds) (2011) El futuro del jaguar en el Gran Chaco-Situación en Bolivia, Paraguay y Argentina. Wildlife Conservation Society, Santa Cruz, Bolivia.

Salvador, S., Clavero, M. \& Pitman, R.L. (2011) Large mammal species richness and habitat use in an upper Amazonian forest used for ecotourism. Mammalian Biology, 76, 115-123.

Sanderson, E.W., Redford, K.H., Chetkiewicz, C.B., Medellin, R.A., Rabinowitz, A.R., Robinson, J.G. \& TABER, A.B. (2002) Planning to save a species: the jaguar as a model. Conservation Biology, 16, 58-72.

Silveira, L.A., JÁcomo, T.A. \& Diniz-Filho, J.A.F. (2003) Camera trap, line transect census and track surveys: a comparative evaluation. Biological Conservation, 114, 351-355.

Taber, A., Navarro, G. \& Arribas, M.A. (1997) A new park in the Bolivian Gran Chaco - an advance in tropical dry forest conservation and community-based management. Oryx, 31, 189-198.

Torrella, S.A. \& Adámoli, J. (2006) Situación ambiental de la ecorregión del chaco seco. In La Situación Ambiental Argentina 2005 (eds A. Brown, U. Martinez Ortiz, M. Acerbi \& J. Corchera), pp. 75-82. Fundación Vida Silvestre Argentina, Buenos Aires, Argentina.
Torres, R. \& Jayat, J.P. (2010) Modelos predictivos de distribución para cuatro especies de mamíferos (Cingulata, Artiodactyla y Rodentia) típicas del Chaco en Argentina. Mastozoología Neotropical, 17, 335-352.

Yackulic, C.B., Sanderson, E.W. \& Uriarte, M. (2011) Anthropogenic and environmental drivers of modern range loss in large mammals. Proceedings of the National Academy of Sciences, 108, 4024-4029.

\section{Biographical sketches}

Verónica Andrea Quiroga has conducted ecological and conservation research on large mammals in Argentina's semiarid Chaco for the past 10 years. She participates in a range of conservation activities for species and ecosystems in Argentina. GABRIEL IVÁn BoAgLio has conducted ecological and conservation research on large mammals in Argentina's semi-arid Chaco for the past 11 years. He also studies bird and mammal populations in the Cordillera region of western Argentina. Andrew JaY Noss has worked with indigenous peoples in the Bolivian Chaco and Ecuadorian lowlands for the past 15 years, on territorial management, conservation of threatened species, including jaguars, and sustainable use of natural resources. MARio SAntiago Di Bitetti has been carrying out research in the subtropical forests and grasslands of northern Argentina for the past 20 years, focusing on the behaviour, ecology and conservation of mammals, particularly primates and carnivores. 